\title{
The Impact of Energy Price Changes in Moldova
}

\author{
Iaroslav Baclajanschi, Lawrence Bouton, Hideki Mori, \\ Dejan Ostojic, Taras Pushak and Erwin R. Tiongson ${ }^{1}$ \\ The World Bank, 1818 H Street, NW, Washington, DC 20433
}

\begin{abstract}
In January 2006, the price of natural gas supplied to Moldova increased from $\$ 80$ to $\$ 110$ per thousand cubic meters (mcm). Prices may increase further in the near future, putting additional pressures on the economy and leading to adverse effects on the poorest households. This study examines the potential impact of higher energy prices on the economy of Moldova by simulating the likely macroeconomic consequences of recent and future price increases. Moreover, it estimates the direct impact on individual households using data drawn from the 2004 Household Budget Survey (HBS). It assesses the distributional implications of the price shock, noting how the social impact may vary depending on the intensity of energy use, geographic location, and the relative share of energy in household expenditure. The results suggest that energy price changes could dampen economic growth while putting additional strains on the current account deficit. The impact on the poorest households could be significant and protecting them may require resources in the amount of 0.7 to 1.7 percent of GDP. This study identifies possible policy responses to dampen the shock of the energy price increase and to promote the longer-term objective of reducing energy vulnerability.
\end{abstract}

JEL Classification Numbers: L95, I32, I39

Keywords: natural gas, prices, macroeconomic impact, poverty

World Bank Policy Research Working Paper 3960, July 2006

The Policy Research Working Paper Series disseminates the findings of work in progress to encourage the exchange of ideas about development issues. An objective of the series is to get the findings out quickly, even if the presentations are less than fully polished. The papers carry the names of the authors and should be cited accordingly. The findings, interpretations, and conclusions expressed in this paper are entirely those of the authors. They do not necessarily represent the view of the World Bank, its Executive Directors, or the countries they represent. Policy Research Working Papers are available online at http://econ.worldbank.org.

\footnotetext{
${ }^{1}$ Corresponding author: Lawrence Bouton, Europe and Central Asia Region, MSN H4-401, World Bank, 1818 H Street, NW, Washington, DC 20433 USA. Tel. (202) 473 9158. email: lbouton@worldbank.org.
} 


\section{The Impact of Energy Price Changes in Moldova ${ }^{2}$}

\section{Introduction}

At the end of 2005, Gazprom announced that it was going to increase the price of natural gas supplied to Moldova from $\$ 80$ to $\$ 160$ per thousand cubic meters (mcm). Unable to conclude an agreement, Gazprom halted the supply of natural gas to Moldova on January 1, 2006. In mid-January, to overcome a looming crisis, a temporary agreement was reached establishing an interim price of $\$ 110 / \mathrm{mcm}$ for the first quarter of 2006 - a 37.5 percent increase- and allowing the resumption in gas supplies from Russia. While this temporary agreement was recently extended through the second quarter, it is expected that there will be pressure for additional increases in the price of natural gas in the coming months. Higher natural gas prices also have implications for heating and electricity prices. One of the main electricity suppliers to Moldova, the gas-fired Cuciurgani power plant (MGRES) in the separatist region of Transnistria, stopped supplying power to Moldova at the end of 2005 after failing to reach agreement on a 30\% increase in the price of electricity supplied. This note examines the potential impact of higher energy prices on the economy of Moldova, explores the distributional implications of these higher prices and discusses the needed policy responses.

\section{Background}

Upon Moldova’s independence in 1991, the massive Soviet energy subsidies as well as guaranteed markets for a variety of agriculture and livestock products came to end. This terms of trade shock, among the largest confronted in the Former Soviet Union (FSU), contributed to Moldova's difficult transition from a command to market economy. ${ }^{3}$ By 2000, per capita GNP was only 40 percent that of 1990 and most Moldovan households were below the poverty line.

In the period following independence, Moldova responded slowly to the rapidly increasing price of energy imports. The government - acting simultaneously as policy maker, regulator, owner and utility manager - was slow in passing the increase to energy consumers and was not able to pay the difference between the supply costs and consumer tariffs. This resulted in a large energy-related quasi-fiscal deficit - estimated at around $5 \%$ of GDP in 1998 - financed in large part through decapitalization of asset base (due to lack of maintenance and investments in energy infrastructure) and accumulation of debt, mainly in the form of payment arrears. With financial discipline weakened and the quality of management deteriorated, companies had increasing difficulty in maintaining supply and shortages in electricity and gas supply developed. This contributed to the accumulation of large external debts and the postponement of much need maintenance and investments in energy infrastructure.

\footnotetext{
${ }^{2}$ Significant input was provided by Sandu Ghidirim. We also received valuable comments from Asad Alam, Paul Bermingham, Edward Brown Robert Gillingham, Nils Junge, David Newhouse, and Peter Thomson. Julian Lampietti provided useful suggestions during the initial stages of this study.

${ }^{3}$ The price of energy increased 40-fold in 1992.
} 
To mitigate the escalating energy crisis, in the late 1990s Moldova embarked on an ambitious set of energy sector reforms. The objective of these reforms was the full commercialization of energy supply, accompanied by appropriate social policies implemented through fiscal instruments to protect the most vulnerable groups (the socalled nominal compensation scheme). The main elements of the reform included: (i) the development of a new, market-oriented legal framework; (ii) restructuring and corporatization of the industry whereby the country's vertically integrated electricity monopoly was unbundled; (iii) privatization of three out of five electricity distribution companies covering about $70 \%$ of the market; (iv) divestiture of state shared in the gas industry with the majority share in the country's monopoly gas supplier sold to Russia's Gazprom in exchange for a portion of debt; and, (v) adjustment to the level and structure of tariffs where tariffs for all consumers where increased and equalized. ${ }^{4}$

As a result of these reforms, payment collections increased especially in the electricity sector. While some collection problems persist, particularly with state-owned entities - such as district heating and water companies - collection rates reached $92 \%$ for gas and $98 \%$ for electricity in 2005. Further, the quasi-fiscal deficit has been significantly reduced and the government has stopped accumulating external debt for gas and electricity imports.

\section{Energy Dependency and Vulnerability}

Moldova is poorly endowed with energy resources and it imports almost all of its primary energy (over 99 percent in 2003). Natural Gas, imported from Russia, comprises nearly two-thirds of energy imports and it is the main fuel for local electricity generation and district heating. Petroleum products account for about 20\% of all energy imports and the electricity imports represent about 10 percent of all energy imports (see Table 1). The power generation system on the right bank of the Nistru river comprises of only three combined heat-and-power plants, covering about one-third of domestic electricity consumption. The rest of Moldova's electricity needs are imported from Ukraine, Transnistria, and, to lesser (and limited) extent, from Romania. Residential
Table 1. 2003 Energy Balance (1000s tons of oil equivalent - ktoe)

\begin{tabular}{|c|c|c|}
\hline & 1000 s tons & Percent \\
\hline \multicolumn{3}{|l|}{ Sources } \\
\hline Total Primary Energy Supply (TPES) & 3,267 & \\
\hline Internal Sources & 61 & \\
\hline Imports & 3,255 & $100 \%$ \\
\hline Petroleum Products & 640 & $20 \%$ \\
\hline Natural Gas & 2,185 & $67 \%$ \\
\hline Coal & 122 & $4 \%$ \\
\hline Electricity & 308 & $9 \%$ \\
\hline Exports & (12) & \\
\hline Stock Changes & (37) & \\
\hline \multicolumn{3}{|l|}{ Uses } \\
\hline TPES & 3,267 & \\
\hline Energy Conversion and Distribution Losses & $(1,519)$ & \\
\hline Total Final Energy Consumption (TFEC) & 1,748 & $100 \%$ \\
\hline Industry Sector & 338 & $19 \%$ \\
\hline Agriculture Sector & 97 & $6 \%$ \\
\hline Transportation Sector & 316 & $18 \%$ \\
\hline Commercial and Public Services & 168 & $10 \%$ \\
\hline Residential & 661 & $38 \%$ \\
\hline Other & 168 & $10 \%$ \\
\hline
\end{tabular}

Source: International Energy Agency, Energy Statistics 2003.

${ }^{4}$ In 2003, ANRE approved differentiated electricity and gas tariffs, reflecting costs, consumption and voltage levels. In 2004, a social tariff for electricity and gas was also introduced - with a reduce price for electricity consumption of up to $50 \mathrm{kWh}$ and a social tariff to residential gas consumers for consumption up to 30 cubic meters per month. 
consumption accounts for about 40 percent of the total final energy consumption (TFEC) due to relatively low share of industrial consumption (only about 19 percent of TFEC). ${ }^{5}$ The second largest consumer of energy is the transport sector which accounts for about 18 percent of TFEC.

The high vulnerability of Moldova to external energy price shock is determined by its dependence on imported natural gas as the main energy source and its high energy intensity which, despite the low level of energy consumption by industry, is relatively high (0.54 tons of oil equivalent (toe)/000\$ of GDP at PPP) - about two times energy intensity of Romania and three times energy intensity of Germany. On the other hand, per capita consumption of energy in Moldova ( 0.77 toe/pc) is significantly below energy consumption in Romania (1.79 toe/pc) and Germany (4.21 toe/pc) which indicates a relative "energy poverty" of Moldova and the demand potential if the country is to achieve its objective of sustainable economic growth and poverty elimination. This also indicates that the most vulnerable categories of consumers may not have much capacity to reduce their demand further in response to the raising energy prices, which underscores the importance of well targeted safety net.

An important element of Moldova's exposure to the energy price shock is the relatively low level of its gas tariffs (about US\$3/Gigajoule (GJ)) in comparison with other countries in the South East Europe (SEE) where average gas prices are in the range of US\$6-7/GJ (see Appendix Figure 1). This implies significant discount at which Moldova has been able to secure gas supplies relative to the European parity price ${ }^{6}$, which was in the order of $\$ 230 / \mathrm{mcm}$ this winter. The electricity price differential is smaller since the average price of electricity in Moldova (6 US cents/kWh) is closer to the average electricity tariffs in the SEE countries (see Appendix Figure 2).

Given its almost complete dependency on imported energy, higher energy prices will immediately result in a larger import bill. If no offsetting financing is available the demand for other imports must be reduced. This implies a reduction in domestic consumption and investment demand and reduced domestic production. The simplest calculation to estimate the direct impact of higher energy prices on GDP is based on the ratio of imports to GDP. ${ }^{7}$ In addition to the size of energy imports relative to GDP, the impact of higher energy prices on GDP will
Table 2: Impact on GDP of Higher Energy Prices

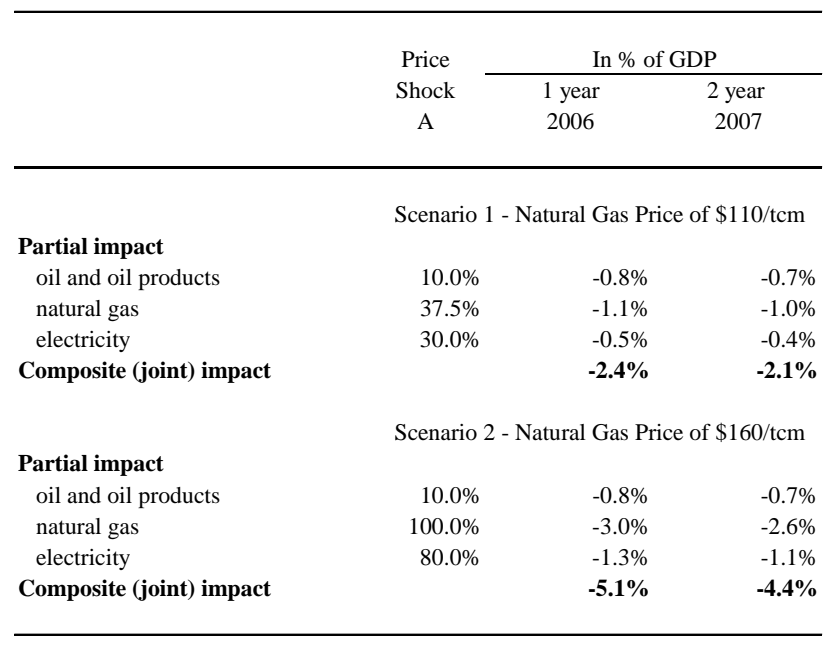

Source: Bank staff calculations.

\footnotetext{
${ }^{5}$ By comparison, industry consumes over $40 \%$ of TFEC in Ukraine and Romania and 30\% in Germany.

${ }^{6}$ The European parity price would be the price of natural gas supplied by Gazprom to Romania and other SEE countries net of transit costs after Moldovan border.

${ }^{7}$ In 2004, energy imports amounted to about 12 percent of GDP (or 18 percent of total imports).
} 
depend on the price elasticity of energy demand (the more inelastic the demand for energy, the more a price increase reduces GDP).

Utilizing a simple net import model, the so-called "terms of trade" impact on GDP of higher energy prices is presented in Table 2. These calculations can be viewed as an indicator of the severity of the price shock on the economy (but it remains a very static view of what would otherwise be a dynamic adjustment in the economy). As in the rest of the note, two different scenarios are presented. The first scenario incorporates the increase in natural gas prices to $\$ 110 / \mathrm{mcm}$ (37.5 percent relative to 2005) and assumes that electricity prices will be increased by 30 percent. The second scenario assumes that the increase in natural gas prices will be larger - to $\$ 160 / \mathrm{mcm}$ or 100 percent relative to 2005- and, as a result, electricity prices will also increase faster (by up to 80 percent) ${ }^{8}$. In both scenarios, the increase in petroleum price is assumed to be the same (10 percent). As can be seen from Table 2, in the first scenario higher energy costs can be expected to lower the level of GDP relative to the 2005 base year by $2.4 \%$ in the 2006 and additional $2.1 \%$ in 2007. If the increase in energy prices is even greater, as assumed in scenario 2, the negative impact on GDP will be even larger - lowering GDP by over 5\% in 2006 and $4.4 \%$ in $2007 .^{9}$

As assessment of the more dynamic impacts of higher energy prices on the economy is, of course, a more complex undertaking. Moldova, like the rest of the world, has already been adjusting to higher petroleum prices. The import bill for energy increased by nearly $\$ 150$ million (or nearly 5 percent of GDP) in 2005. This contributed to a widening of the trade deficit from 30 percent of GDP in 2004 to 38 percent in 2005. At the same time, however, remittances (compensation and transfers) grew by nearly \$240 million with the result that the deterioration current account deficit was significantly smaller - the current account deficit widened from 2.7 percent in 2004 to about 5.5 percent in 2005. The inflow of remittance also contributed to strong consumption growth with the result that real GDP growth remained strong in 2005 with growth reaching 7.1 percent. At the same time, tight monetary and fiscal policy helped contain inflationary pressures and the year end inflation rate was 10 percent - a decline relative to 2004 (which ended the year with an inflation rate of 12.6 percent).

The increase in natural gas prices in 2006 will put additional pressures on the economy. In particular, we estimate that higher energy prices will have the following impacts:

Economic Growth: Prior to the revision in natural gas prices, it was assumed that the Moldovan economy would begin slowing down. The rapid increase in remittances experienced by Moldova will unlikely be sustained in the medium term and, hence, will contribute to a slowing down in consumption and construction activity over

\footnotetext{
${ }^{8}$ This assumption is based on the marginal cost of electricity produced in gas-fired power plants (such as MGRES) where the short-run cost is mainly cost of natural gas.

${ }^{9}$ The price elasticity of demand for energy in Moldova is assumed to be 0.055 in the first year and 0.2 in the second year. That is, a 100 increase in prices will reduce demand by 5.5 percent in the first year and 20 percent in the second. No change in the transit fees for natural gas is assumed under this simple model.
} 
the medium term. The increase in the cost of energy experienced to date will, along with this expected slowdown in remittance growth, contribute to slower economic growth. Given these current energy prices, over the medium term, economic growth is expected to slow to around 5 percent per annum. If natural gas prices are increased still further (i.e. to $\$ 160 / \mathrm{mcm}$ ) economic growth can be expected to slow by an additional $0.5-1.0$ percentage points, mainly through the impact on reduced consumption. The manufacturing sector in Moldova is a relatively small share of the economy, with the energy-intensive industries in particular accounting for a minor share of this sector.

External Position: Moldova is a very open economy. Imports of goods and services reached nearly 90 percent of GDP in 2005 with energy imports amount to around 15 percent of GDP. The slowdown in domestic consumption, and hence imports, will help offset some of the impacts of higher energy prices on the external position. With gas prices at $\$ 110 / \mathrm{mcm}$ the current account deficit will likely remain slightly above 5 percent of GDP in the next few years. If, however, gas prices were to rise to $\$ 160 / \mathrm{mcm}$, then that deficit will likely widen further (by around 1.5-2.0 percent of GDP) with the deficit remaining in the 6-7 percent of GDP in the near term. The widening current account deficit will put pressure on Moldova's otherwise stable exchange rate and some depreciation can be expected (by about 5-10 percent).

Fiscal Policy: An increase in natural gas prices will contribute to a widening of the fiscal deficit given the higher direct consumption costs by the government as well as lower revenues - consumption of imports will be shifted towards natural gas which is subject to a lower VAT rate since Russia continues to collect indirect taxes at origin on gas exports to Moldova. Under the IMF PRGF program - predicated on a natural gas price of around $\$ 110 / \mathrm{mcm}$ - fiscal policy is programmed to remain tight with an overall deficit of 0.5 percent of GDP. If natural gas prices were to increase further, it can be expected to add an additional 0.5-0.8 percent of GDP to the deficit.

Inflation: Under the IMF program, fiscal and monetary policy is expected to remain tight contributing, along with slower growth, to reduced inflationary pressures despite higher energy prices (i.e. gas at $\$ 110 / \mathrm{mcm}$ ). Inflation, under this program, is targeted to fall and remain in the single digits over the program period. If, however, natural gas prices were to increase further, some additional inflationary pressures can be expected because of the pass through effect. While prudent fiscal and monetary policy will contribute to the maintenance of price stability (with the openness of the Moldova economy also contributing), inflation will likely be closer to 12-15 percent. 


\section{Distributional Implications of Higher Energy Costs}

While the energy price shocks can be expected to have broad macroeconomic implications, the distributional impact of these higher prices will differ across households and location (i.e., large cities, small towns and rural areas). ${ }^{10}$ In the first instance, the direct impact of higher energy costs on individual households will depend on whether that household is a consumer of gas and/or other energy products. In addition, the distributional impact also depends on how the intensity of energy use or consumption level varies across household quintiles and geographic location. Finally, the impact depends on the relative share of gas and energy products in total household expenditure. Households who spend larger shares of their budgets on energy are expected to bear a greater burden of the price increase.

\section{Who are connected?}

Almost all households are connected to electricity while the connection rates for central heating and central gas and the consumption incidence of liquefied petroleum gas (LPGs) vary by location. As shown in Table 3, while over 70 percent of households in large cities (Chisinau and Balti) and small towns are connected to central gas services, only 11 percent of rural house are connected. ${ }^{11}$ On the other hand, most rural households consume gas cylinders or liquefied petroleum gas (LPG) while few households in large cities consume them. About a quarter of all households and over three-quarters of households in small towns and rural areas, respectively, consume LPG. As for electricity, virtually all households are connected. Central heating, on the other hand, is mainly an urban consumption item.

\footnotetext{
${ }^{10}$ Energy expenditures are extracted from Moldova Household Budget Survey 2004, a survey conducted every year since 1997. By design, about 660 households are sampled to be interviewed each month. As it is virtually impossible to achieve a 100 percent response rate, in 2004 the total number of observations in the final dataset is 6121 . Collection rates are relatively high across energy products (or have been steadily increasing, where collection rates have been historically low, such as in heating) and this increases confidence in the general reliability of HBS data. The consumption aggregate created by the World Bank's poverty assessment team is used as a proxy of household welfare, with a single modification. The poverty assessment team excluded three consumption categories (utility, housing, and durables) from final consumption aggregate (see also World Bank, 2004). For the purposes of this analysis, however, utility expenditures are included and the new per capita consumption quintiles are based on this adjusted aggregate.

${ }^{11}$ There is an additional geographic dimension to connection rates and consumption: The few rural households connected to central gas tend to be concentrated in a few specific localities, due to the Moldovan Village Program and the multi-year program aimed at gradually connecting all villages to the gas network.
} 
Table 3. Connection Rates, 2004

(In percent of all households)

\begin{tabular}{|c|c|c|c|c|}
\hline \multirow[b]{2}{*}{ Quintile } & \multicolumn{4}{|c|}{ Energy Product } \\
\hline & $\begin{array}{c}\text { Central Gas } \\
\text { (1) }\end{array}$ & $\begin{array}{l}\text { LPG } \\
(2)\end{array}$ & $\begin{array}{l}\text { Electricity } \\
\text { (3) }\end{array}$ & $\begin{array}{c}\text { Central Heat } \\
\text { (4) }\end{array}$ \\
\hline \multicolumn{5}{|l|}{ A. All households } \\
\hline Poorest & 22.5 & 68.5 & 97.3 & 9.1 \\
\hline Second & 30.2 & 62.1 & 98.9 & 16.2 \\
\hline Third & 31.3 & 61.4 & 99.6 & 20.8 \\
\hline Fourth & 37.5 & 55.5 & 99.6 & 28.3 \\
\hline Richest & 47.8 & 38.7 & 99.8 & 44.5 \\
\hline All & 35.2 & 55.7 & 99.2 & 25.7 \\
\hline \multicolumn{5}{|l|}{ Of which: } \\
\hline \multicolumn{5}{|c|}{ A1. Large Cities } \\
\hline Poorest & 67.0 & 0.0 & 97.2 & 97.8 \\
\hline Second & 66.0 & 3.4 & 97.3 & 97.8 \\
\hline Third & 69.5 & 1.9 & 99.4 & 98.2 \\
\hline Fourth & 76.2 & 0.7 & 99.7 & 97.8 \\
\hline Richest & 69.6 & 1.6 & 99.8 & 95.3 \\
\hline All & 70.8 & 1.5 & 99.4 & 96.7 \\
\hline \multicolumn{5}{|c|}{ A2. Small towns } \\
\hline Poorest & 67.8 & 29.9 & 95.8 & 19.2 \\
\hline Second & 73.7 & 25.0 & 99.6 & 20.0 \\
\hline Third & 76.0 & 23.7 & 99.6 & 21.2 \\
\hline Fourth & 74.2 & 25.4 & 99.6 & 13.3 \\
\hline Richest & 78.4 & 21.6 & 100.0 & 12.6 \\
\hline All & 74.1 & 25.0 & 99.0 & 17.4 \\
\hline \multicolumn{5}{|c|}{ A3. Rural areas } \\
\hline Poorest & 7.3 & 83.7 & 97.8 & $\ldots$ \\
\hline Second & 11.5 & 83.2 & 98.9 & $\ldots$ \\
\hline Third & 9.1 & 87.4 & 99.7 & $\ldots$ \\
\hline Fourth & 10.6 & 88.3 & 99.6 & $\ldots$ \\
\hline Richest & 15.4 & 83.4 & 99.8 & $\ldots$ \\
\hline All & 10.7 & 85.4 & 99.2 & $\ldots$ \\
\hline
\end{tabular}

Source: HBS and Bank staff calculations.

Note: "..." indicate insufficient observations. 
Who spends the most on energy in absolute terms?

In absolute terms, expenditure on gas and energy products is generally progressive across all locations. Average monthly household expenditures on gas, electricity and central heating, across quintiles and location are summarized in Appendix Table $1 .{ }^{12}$ In absolute terms, richer households spend more on energy than poorer households. Central gas spending of households in large cities is not strongly regressive; consumption levels are more or less even across the first four quintiles. As for LPG, poorer households generally spend a little more than richer households. This is not surprising, given the relatively lower central gas connection rates among poorer households; LPG thus serves to some extent as substitute to central gas.

Expenditure levels in absolute terms vary across energy products and across geographical locations. Rural households appear to have the highest expenditures on central gas and lowest on electricity, while the opposite is true for large cities. This primarily reflects housing peculiarities of urban and rural households, with central gas being used typically for cooking (and very rarely for heating dwellings) in large cities but for both cooking and heating in rural areas where it is available.

\section{What are the expenditure shares of energy?}

Electricity expenditures are more burdensome for poorer households and account for a larger share of household expenditure than all other gas and energy products combined. Since payment capability varies substantially across Moldovan population, it is critical to look at distributional impacts of potential tariff changes in relative terms. Taking all households together-where both unconnected households as well as households that are connected but have missing expenditure data are assumed to have zero expenditures on energy-electricity expenditures account for almost 5 percent of household budgets, on average, while other gas and energy products account for 0.5 to 1.8 percent of budgets (Table 4, Item A). Spending on electricity is somewhat regressive: the poorest quintile spends 5.4 percent of their budget on electricity while the richest quintile spends only 3.6 percent - which indicates relatively inelastic demand for basic electricity uses such as lighting. In contrast, the richest quintile spend a larger share of their budget on central heat (1.8) compared to the lowest quintile (0.1). The expenditure patterns for central gas and LPG, on the other hand, are neither clearly regressive nor progressive when looking across all households across all locations together.

\footnotetext{
${ }^{12}$ Two pieces of information drawn from the 2004 HBS allow us to calculate the average monthly expenditures on gas and energy. The first is the reported magnitude of expenditure. The second is the reference period for the reported expenditures. The second piece of information is drawn from a new survey question introduced in the 2004 HBS. Seasonality of consumption presents one methodological challenge, particularly in the case of central heating. The HBS data reports expenditures on central heating year-round. This may reflect the design of the billing cycle which allows for expenditure to be spread over the entire year. The estimates reported in this note, therefore, are based on the assumption that the observed expenditures on central heating do, in fact, reflect actual spending patterns.
} 
Table 4. Average Expenditure Share of Energy Products

(By expenditure quintile and location in percent of total household consumption)

\begin{tabular}{|c|c|c|c|c|}
\hline \multirow[b]{2}{*}{ Quintile } & \multicolumn{4}{|c|}{ Energy Product } \\
\hline & $\begin{array}{c}\text { Central Gas } \\
\text { (1) }\end{array}$ & $\begin{array}{c}\text { LPG } \\
(2)\end{array}$ & $\begin{array}{l}\text { Electricity } \\
\text { (3) }\end{array}$ & $\begin{array}{c}\text { Central Heat } \\
\text { (4) }\end{array}$ \\
\hline \multicolumn{5}{|c|}{ A. All households ${ }^{1}$} \\
\hline Poorest & 1.0 & 0.4 & 5.4 & 0.1 \\
\hline Second & 1.8 & 0.4 & 4.9 & 0.4 \\
\hline Third & 1.7 & 0.4 & 4.9 & 1.0 \\
\hline Fourth & 2.1 & 0.5 & 4.5 & 1.5 \\
\hline Richest & 1.9 & 0.4 & 3.6 & 1.8 \\
\hline All & 1.8 & 0.4 & 4.6 & 1.1 \\
\hline \multicolumn{5}{|c|}{ B. Connected households with positive expenditures ${ }^{2}$} \\
\hline Poorest & 6.4 & 11.3 & 6.5 & $\ldots$ \\
\hline Second & 7.1 & 8.7 & 5.6 & 14.4 \\
\hline Third & 6.6 & 7.1 & 5.5 & 16.1 \\
\hline Fourth & 6.3 & 6.3 & 5.0 & 15.8 \\
\hline Richest & 4.6 & 4.4 & 4.3 & 11.0 \\
\hline All & 5.9 & 6.5 & 5.2 & 13.4 \\
\hline \multicolumn{5}{|l|}{ Of which: } \\
\hline \multicolumn{5}{|c|}{ B1. Large Cities } \\
\hline Poorest & 5.5 & $\ldots$ & 7.8 & $\ldots$ \\
\hline Second & 3.6 & $\ldots$ & 8.0 & 14.3 \\
\hline Third & 3.2 & $\ldots$ & 7.9 & 16.1 \\
\hline Fourth & 2.6 & $\ldots$ & 6.9 & 15.8 \\
\hline Richest & 2.1 & $\ldots$ & 5.3 & 11.0 \\
\hline \multicolumn{5}{|c|}{ B2. Small towns } \\
\hline Poorest & 7.3 & 13.2 & 7.9 & $\ldots$ \\
\hline Second & 8.4 & 12.0 & 6.8 & $\ldots$ \\
\hline Third & 8.6 & 10.5 & 6.3 & $\ldots$ \\
\hline Fourth & 10.6 & 8.8 & 5.6 & $\ldots$ \\
\hline Richest & 10.4 & 6.3 & 4.8 & $\ldots$ \\
\hline \multicolumn{5}{|c|}{ B3. Rural areas } \\
\hline Poorest & 5.0 & 10.0 & 6.1 & $\ldots$ \\
\hline Second & 7.9 & 8.0 & 5.0 & $\ldots$ \\
\hline Third & 8.3 & 6.4 & 4.7 & $\ldots$ \\
\hline Fourth & 10.2 & 5.8 & 4.2 & $\ldots$ \\
\hline Richest & 7.6 & 4.2 & 3.3 & $\ldots$ \\
\hline
\end{tabular}

Source: HBS and Bank staff calculations.

Note: "..." indicate insufficient observations.

${ }^{1}$ Unconnected households as well as households that are connected but have missing expenditure data are assumed to have zero expenditures on energy.

${ }^{2}$ Includes only households that are connected and are reporting expenditure information. Implicitly, the calculations include households that are connected but have missing expenditure data, and these households are assumed to have expenditure levels equal to average expenditures by quintile and location. 
Aggregate numbers based on both connected and unconnected households may mask important variations and distributive dimensions. Focusing only on households that are connected and have positive expenditures on gas and energy products reveals a number of important patterns (see Item B in Table 4):

First, the expenditure shares of gas and energy products are large when the calculations are restricted to households that are connected and have positive expenditures of gas and energy products. ${ }^{13}$ On average, for these households, gas products and electricity account for 5 to 6 percent of households budgets. As for central heat, spending amounts to about 13 percent of household budgets in large cities.

Second, whether the expenditure patterns are progressive or regressive depends on the energy product and geographic location (see Items B1 to B3 in Table 4). For example, central gas expenditures in large cities are a greater burden on poor households. In small towns and rural areas, however, richer households spend a larger share of their income on central gas. On the other hand, expenditure on LPG is consistently more burdensome for the poor, accounting for at least 10 percent of the budgets of the poorest quintiles. Central heating, on the other hand, is mostly a consumption item in large cities and is neither clearly progressive nor regressive. Electricity expenditures are more burdensome for poorer households across all locations.

\section{What is the short-term distributional impact of the gas price increase?}

The impact on households of higher energy tariffs is modeled under two different scenarios. In the first, natural gas and central heating prices are increased by 37.5 percent to reflect a natural gas price of $\$ 110 / \mathrm{mcm}$ up from the $\$ 80 / \mathrm{mcm}$ price that prevailed until early 2006. Electricity prices under this scenario are assumed to increase by 30 percent given the importance of gas in electricity generation. ${ }^{14}$ In the second scenario, where the price of imported natural gas is expected to increase to $\$ 160 / \mathrm{mcm}$, central gas and heating tariffs are expected to increase by 100 percent while electricity tariffs rise by 80 percent, proportional to the gas price increase. Because the impact is largely a function of expenditure levels and shares, the expected distributional effects are consistent with variations in consumption levels and expenditure shares documented in the previous section.

In absolute terms, the effect of the price increase is generally progressive. Increasing gas, electricity, or central heating tariffs would cause bills of richer households to grow by a greater absolute amount than those of poorer ones, because of the higher intensity of energy use (except for LPG) among richer households.

\footnotetext{
${ }^{13}$ One of the fundamental problems in dealing with household budget data is the treatment of missing values. Implicitly, the second set of calculations (Item B in Table 4) also includes households that are connected but having missing expenditure information. The Methodology assumes that these households have expenditure levels equal to the average expenditure of the reporting households.

${ }^{14}$ The assumption of a 30 percent increase is consistent with the relative share of fuel in the production cost of gas-fired power plants supplying electricity to Moldova. This is also consistent with the price increase requested by one of the main electricity suppliers at the end of 2005.
} 
In relative terms, however, the distributional impact varies depending on whether all households, both connected and unconnected, or only the sub-sample of households that are connected and reporting positive expenditures are included in the calculations. Table 5 reports summary information the impact of the gas price increase, under the two scenarios, expressed in percent of household expenditure. The calculations allow for some substitution away from the relatively more expensive goods. ${ }^{15}$

The cumulative impact of higher energy costs, expressed in percent of household expenditures, is neither strongly progressive nor regressive. For Moldova as a whole, taking all households together-both connected and unconnected households - the combined impact of the price increase of all gas and energy products is neither progressive nor regressive (Table 5, Item A). However, the impact in percent of household expenditures can be quite large. Under the second scenario, for example, the cumulative impact of the rising cost of energy is between 4 and 5.5 percent of household budgets.

Among connected households that are reporting expenditure information, the distributional effect of the price increase, expressed in percent of household expenditures, varies by location and by energy product (Table 5, Items B to B3). Rising tariffs on central gas and LPG will impact all households in small towns and in rural areas, while growing central heating costs will be the most painful for dwellers of large cities. Not surprisingly, because almost all households are connected to electricity, its increasing cost will be burdensome for households across all locations. Its impact is also consistently regressive across all locations. Similarly, there are regressive effects following the LPG price hike in small towns and rural areas. Rising central gas tariffs have somewhat regressive effects in large cities and progressive effects everywhere else. The impact of the increasing cost of central heating is neither regressive nor progressive.

The effects on the budgets of connected households can be large, particularly for the poorest households (Table 5, Items B to B3). For example, for the poorest households, the price increase of LPG under the two scenarios amounts to 3.2 to 7.2 percent of their budget in rural areas and 4.3 to 9.6 percent of their budget in small towns. In contrast, the price increase amounts to 2 to 4.5 percent and 1.4 to 3 percent of the budgets of the richest households in rural areas and small towns, respectively. Even for energy products that are projected to have progressive effects - that is, tariff increases reflect a larger share of the budgets of the richer households-the impact on the poorest

\footnotetext{
${ }^{15}$ This is based on a geometric mean of the relative price change where consumption behavior is assumed to be responsive to a change in relative prices and households substitute consumption away from the relatively more expensive good (see also Pollak, 1989; Gupta and others, 2000; U.S. Bureau of Labor Statistics, 1997; Dalton, Greenlees and Stewart, 1998). Alternatively, one could assume zero substitution (arithmetic mean) corresponding to the case when consumption levels (quantities) remain fixed following a price increase (see, for example, Freund and Wallich, 1997). There is empirical evidence that the elasticity of electricity and gas consumption is about 0.1 , i.e., 100 percent increase in the price of gas/electricity would cause a 10 percent reduction in consumption. Thus, impact estimates that allows for some substitution may be more appropriate. However, the estimated effects based on zero substitution, though of larger magnitudes, are in the same direction as those reported in Table 4. See Appendix Table 2.
} 
households is not trivial. For example, the impact of rising central gas tariffs amount to 2.4 to 5.2 percent of the budgets of the poorest households in small towns.

Table 5. Impact of Gas Price Increase

(By expenditure quintile and location in percent of total household consumption)

\begin{tabular}{|c|c|c|c|c|c|c|c|c|}
\hline \multirow[b]{2}{*}{$\begin{array}{l}\text { Magnitude of price increase/ } \\
\text { Quintile }\end{array}$} & \multicolumn{4}{|c|}{ Scenario 1: Impact by Energy Product } & \multicolumn{4}{|c|}{ Scenario 2: Impact by Energy Product } \\
\hline & $\begin{array}{c}\text { Central Gas } \\
37.5 \% \\
(1)\end{array}$ & $\begin{array}{c}\text { LPG } \\
37.5 \% \\
(2)\end{array}$ & $\begin{array}{c}\text { Electricity } \\
30 \% \\
(3)\end{array}$ & $\begin{array}{c}\text { Central Heat } \\
37.5 \% \\
\text { (4) }\end{array}$ & $\begin{array}{c}\text { Central Gas } \\
100.0 \% \\
\text { (5) }\end{array}$ & $\begin{array}{c}\text { LPG } \\
100.0 \% \\
(6)\end{array}$ & $\begin{array}{c}\text { Electricity } \\
80 \% \\
(7)\end{array}$ & $\begin{array}{c}\text { Central Heat } \\
100.0 \% \\
\text { (8) }\end{array}$ \\
\hline \multicolumn{9}{|l|}{ A. All households ${ }^{1}$} \\
\hline Poorest & 0.3 & 0.1 & 1.4 & 0.0 & 0.7 & 0.3 & 3.2 & 0.1 \\
\hline Second & 0.6 & 0.1 & 1.3 & 0.1 & 1.3 & 0.3 & 2.9 & 0.3 \\
\hline Third & 0.5 & 0.1 & 1.3 & 0.3 & 1.2 & 0.3 & 2.9 & 0.7 \\
\hline Fourth & 0.7 & 0.2 & 1.2 & 0.5 & 1.4 & 0.3 & 2.7 & 1.1 \\
\hline Richest & 0.6 & 0.1 & 0.9 & 0.6 & 1.3 & 0.3 & 2.1 & 1.2 \\
\hline \multicolumn{9}{|c|}{ B. Connected households with positive expenditures ${ }^{2}$} \\
\hline Poorest & 2.1 & 3.7 & 1.7 & $\ldots$ & 4.5 & 8.2 & 3.9 & $\ldots$ \\
\hline Second & 2.3 & 2.8 & 1.5 & $\ldots$ & 5.1 & 6.2 & 3.4 & $\ldots$ \\
\hline Third & 2.1 & 2.3 & 1.5 & $\ldots$ & 4.7 & 5.0 & 3.3 & $\ldots$ \\
\hline Fourth & 2.1 & 2.0 & 1.3 & $\ldots$ & 4.7 & 4.4 & 3.0 & $\ldots$ \\
\hline Richest & 1.5 & 1.4 & 1.2 & $\ldots$ & 3.4 & 3.1 & 2.7 & $\ldots$ \\
\hline \multicolumn{9}{|l|}{ Of which: } \\
\hline \multicolumn{9}{|l|}{ B1. Large Cities } \\
\hline Poorest & 1.8 & $\ldots$ & 2.3 & $\ldots$ & 3.9 & $\ldots$ & 5.2 & $\ldots$ \\
\hline Second & 1.2 & $\ldots$ & 2.1 & 4.7 & 2.7 & $\ldots$ & 4.8 & 10.4 \\
\hline Third & 1.0 & $\ldots$ & 2.2 & 5.3 & 2.2 & $\ldots$ & 4.9 & 11.8 \\
\hline Fourth & 1.0 & $\ldots$ & 1.9 & 5.2 & 2.1 & $\ldots$ & 4.3 & 11.6 \\
\hline Richest & 0.7 & $\ldots$ & 1.5 & 3.6 & 1.6 & $\ldots$ & 3.5 & 7.9 \\
\hline \multicolumn{9}{|l|}{ B2. Small towns } \\
\hline Poorest & 2.4 & 4.3 & 2.1 & $\ldots$ & 5.2 & 9.6 & 4.7 & $\ldots$ \\
\hline Second & 2.7 & 3.9 & 1.8 & $\ldots$ & 6.1 & 8.7 & 4.1 & $\ldots$ \\
\hline Third & 2.8 & 3.4 & 1.7 & $\ldots$ & 6.3 & 7.6 & 3.8 & $\ldots$ \\
\hline Fourth & 3.6 & 2.9 & 1.5 & $\ldots$ & 7.9 & 6.3 & 3.4 & $\ldots$ \\
\hline Richest & 3.5 & 2.0 & 1.3 & $\ldots$ & 7.8 & 4.5 & 2.9 & $\ldots$ \\
\hline \multicolumn{9}{|l|}{ B3. Rural areas } \\
\hline Poorest & 1.6 & 3.2 & 1.6 & $\ldots$ & 3.5 & 7.2 & 3.7 & $\ldots$ \\
\hline Second & 2.6 & 2.6 & 1.3 & $\ldots$ & 5.8 & 5.7 & 3.0 & $\ldots$ \\
\hline Third & 2.7 & 2.1 & 1.3 & $\ldots$ & 6.0 & 4.6 & 2.9 & $\ldots$ \\
\hline Fourth & 3.3 & 1.9 & 1.1 & $\ldots$ & 7.4 & 4.1 & 2.5 & $\ldots$ \\
\hline Richest & 2.5 & 1.4 & 0.9 & $\ldots$ & 5.5 & 3.0 & 2.0 & $\ldots$ \\
\hline
\end{tabular}

Source: HBS and Bank staff calculations.

Note: "..." indicate insufficient observations. Based on a geometric mean of the relative price change.

${ }^{1}$ Unconnected households as well as households that are connected but have missing expenditure data are assumed to have zero expenditures on energy.

${ }^{2}$ Includes only households that are connected and are reporting expenditure information. Implicitly, the calculations include households that are connected

but have missing expenditure data, and these households are assumed to have expenditure levels equal to average expenditures by quintile and location.

What is the fiscal cost of protecting the poorest households?

Under the same two scenarios for natural gas price increase, the aggregate increase in expenditures on gas and energy products is estimated. The upper bound on the aggregate increase is calculated by assuming that consumption levels are unchanged (no substitution). The estimates reflect the effective cost of protecting all or selected 
Table 6. Aggregate Increase in Expenditures on Gas and Energy Products

\begin{tabular}{|c|c|c|c|c|c|}
\hline \multirow{2}{*}{$\begin{array}{l}\text { Natural Gas Price } \\
\text { Quintile }\end{array}$} & \multicolumn{2}{|c|}{$\begin{array}{c}\text { Scenario } 1^{1} \\
\$ 110 / \mathrm{tcm} \\
\end{array}$} & \multicolumn{2}{|c|}{$\begin{array}{c}\text { Scenario } 2^{1} \\
\$ 160 / \text { tcm } \\
\end{array}$} & \multirow[b]{2}{*}{ Distribution } \\
\hline & 1000s lei & $\%$ of GDP & 1000s lei & $\%$ of GDP & \\
\hline \multicolumn{6}{|c|}{ All connected households ${ }^{2}$} \\
\hline Poorest & 88,637 & 0.3 & 236,366 & 0.7 & 10.2 \\
\hline Second & 118,697 & 0.4 & 316,525 & 1.0 & 13.6 \\
\hline Third & 153,824 & 0.5 & 410,199 & 1.3 & 17.6 \\
\hline Fourth & 211,584 & 0.7 & 564,224 & 1.8 & 24.2 \\
\hline Richest & 297,627 & 0.9 & 793,671 & 2.5 & 34.1 \\
\hline Total & 872,949 & 2.7 & $2,327,863$ & 7.3 & 100.0 \\
\hline \multicolumn{6}{|c|}{ B. Connected households with positive expenditures ${ }^{3}$} \\
\hline Poorest & 30,535 & 0.1 & 81,426 & 0.3 & 6.9 \\
\hline Second & 52,836 & 0.2 & 140,896 & 0.4 & 11.9 \\
\hline Third & 76,053 & 0.2 & 202,808 & 0.6 & 17.1 \\
\hline Fourth & 114,484 & 0.4 & 305,290 & 1.0 & 25.8 \\
\hline Richest & 170,434 & 0.5 & 454,490 & 1.4 & 38.4 \\
\hline Total & 444,336 & 1.4 & $1,184,896$ & 3.7 & 100.0 \\
\hline
\end{tabular}

Source: HBS and Bank staff calculations.

${ }^{1}$ See Table 4 and main text for a description of the two scenarios.

${ }^{2}$ These simulations assume that connected households with missing expenditure data have energy

expenditure levels equal to the average expenditure levels of households with non-missing

observations.

${ }^{3}$ These simulations exclude connected households with missing expenditure data.

household quintiles, to keep them as well off as they were prior to the energy price increases. ${ }^{16}$

\footnotetext{
${ }^{16}$ Table 5 presents two sets of estimates: The first assumes that connected households with missing expenditure data are spending the average amount of expenditures on energy. The second excludes households with missing expenditure data. Clearly these are two extreme assumptions. The first set of estimates is arguably upward biased because connected households are not necessarily consuming positive amounts of energy or may not be paying for the energy they consume. On the other hand, the second set of estimates could be downward biased because missing expenditure data may be due to any number of factors, including infrequency of payments, inability to identify energy product-specific expenditures, or the simple failure to report such expenditures in the HBS. The high collection rates across energy products
} 
Protecting the energy consumption of households from the two poorest quintiles requires energy subsidies of about 0.7 to 1.7 percent of GDP under the two scenarios. ${ }^{17}$ When the calculations are restricted to connected and paying households, the fiscal cost is much lower: 0.3 percent of GDP under the first scenario and 0.7 percent of GDP under the second scenario. However, these calculations assume that households in the poorest quintiles can be perfectly targeted by safety nets. In practice, they are not. The 2004 Poverty Assessment (World Bank, 2004), in particular, finds that some 32.9 percent of the budget on gas and energy compensations accrue to the non-poor. Some 44 percent of recipients are non-poor.

\section{Other costs}

The rising cost of energy may have significant health and environmental costs as households switch to cheaper sources of fuel. Based on the results of focus group discussions, for example, some rural households in Moldova were found to rarely cook or heat with electricity; they typically use wood, coal, or gas instead. ${ }^{18} \mathrm{HBS}$ data is not likely to provide a reliable estimate of the switch to dirty fuel following the rising cost of network sources of energy, because there are few observations on wood or coal use. However, it is reasonable to expect that with the price of electricity and natural gas increasing, households (and rural households, in particular, who are more likely to be poor) will indeed switch to less expensive but dirtier sources of energy and this may lead to significant health and environmental costs. For example, burning dirty fuels may degrade indoor and outdoor air quality, and this, in turn may lead to worsening health outcomes. In addition, burning wood promotes deforestation and contributes to the loss of valuable forest functions. ${ }^{19}$

\section{Policy Implications}

It is clear that Moldova is highly vulnerable to gas price increases, and that upward price pressures are likely to be a fact of life in the coming years. In developing and implementing its policy response, the government should recognize that: (a) gas imports are likely to continue to play pivotal role in the energy balance of Moldova in the long term; and (b) Moldova has in its hands the task of reducing its energy vulnerability by improving energy efficiency, reducing energy waste and developing alternative energy resources. The following recommendations provide a broad roadmap for policy makers in Moldova in this regard.

also suggest that many of the missing expenditure data are not necessarily due to nonpayment. The two sets of calculations should thus be treated as an indicative range of estimates.

${ }^{17}$ The most recent Poverty Assessment finds that the poverty rate is close to 40 percent. The two poorest quintiles provide a rough approximation of households in poverty.

${ }^{18}$ Junge and others, 2004, Sharing Power: Lessons Learned from the Reform and Privatization of Moldova's Electricity Sector (Washington: The World Bank).

${ }^{19}$ See Lampietti, ed., 2004, Power's Promise: Electricity Reforms In Eastern Europe And Central Asia (Washington: The World Bank). 
- Gradually increase utility service tariffs (for gas, electricity and heat) to full cost recovery level, while maintaining financial discipline in order to avoid quasifiscal activities associated with non-payments, accumulation of debts and decline in the scope of maintenance activities;

- Maintain hard budget constraints on energy producers, suppliers and consumers to encourage them to save energy, invest in modernization of asset base and energy efficiency ${ }^{20}$;

- Identify administrative, regulatory and other impediments for investments in energy efficiency and alternative energy resources. Develop and implement measures to increase incentives and facilitate investments in energy efficiency and alternative (renewable) energy resources, including use of flexible mechanisms under the Kyoto Protocol; and

- Improve institutional capacity in the government for contingency planning and rapid response to an uncertain evolution of energy prices in the medium-term, particularly from the point of view of their impact on the most vulnerable population groups.

Oil and gas price pressures are driven by market forces that are essentially beyond the influence of policy makers in Moldova, except for the policies governing energy (gas and electricity) transits through Moldova. In this area, Moldova should aim to establish a record of good transit country and preferred route for the energy trade between the CIS energy market and the South East European (SEE) energy market, which is a part of the EU Internal Energy Market. Adopting and implementing principles governing the Energy Community of SEE (ECSEE), in which Moldova participates as observer, would go a long way in improving transparency and regulation in the energy sector which are key in attracting energy trade and related investments. Key measures in this regard include:

- Perform benchmarking of the energy sector legislation in relation to provisions of the ECSEE Treaty and the EU energy (gas and electricity) directives and identify compliance barriers;

- Based on the legal benchmarking, develop and implement necessary adjustments in the market design and the regulatory framework to allow for a gradual opening of the gas and electricity market in line with the ECSEE Treaty and the EU directives; and

- Mobilize investments needed to expand (and/or free) transmission capacity on the main energy trade corridors with Ukraine and the South East Europe, including investments required for interconnection of Moldova's power grid with the UCTE.

\footnotetext{
${ }^{20}$ Where energy consumption is not metered and where payments are based on household or dwelling characteristics, there is scope for increasing efficiency through individual metering.
} 
The government may wish to consider several options for dampening the shock of energy price increase to the poor. An apparent option is to utilize the existing Nominal Compensation Program, which has already been providing utility subsidies to selected categories of population. ${ }^{21}$ At present, the Program is not means-tested and as a result, its poverty targeting efficiency is not very high. Nonetheless, the government is about to implement a pilot targeting measures with the assistance of EU-FSP in a small number of raions. If the experience of the pilot program proves to be positive, the government may wish to accelerate the application of the targeting mechanism to the rest of the country.

Nominal compensations are increasing in real terms but more slowly than other allowances. Rationalizing other allowances could provide some space for reallocating resources to nominal compensations, in particular, using some of the revenues of the Republican Fund for the Support of the Population to pay for a temporary expansion of the Nominal Compensation Program. These revenues are extra-budgetary. While the spending from the Fund is increasing, the efficiency and effectiveness of the spending leave rooms for improvement.

Finally, should the government decide to use the Nominal Compensation Program or other mechanism to dampen the impact of the energy cost shock, it will be highly desirable to build an effective sunset clause in the mechanism. If not, such a program will be highly vulnerable to political pressures to extend it permanently. First, the government should communicate clearly and widely that the measure will be temporary. Second, it is advisable to make program renewals more difficult by requiring supermajority ( $2 / 3$ of votes rather than a simple majority vote of over $50 \%$ ) for any renewal attempt to be approved by the Parliament if possible.

It is also important not to index the value of subsidies to prices or actual utility consumption because doing so would raise expectation for program renewal (in spite of the sunset clause) and prevent the uncontrollable increase of subsidy expenditures. Ideally, the government should like to provide cash benefits based on poverty characteristics of the household, and de-link the provision of cash benefits from the process of utility bill payment (as it is now under the nominative compensation scheme for urban households). In fact, in many countries (including Indonesia and Brazil), the trend is to include (or convert) energy subsidies into part of (proxy-)means tested comprehensive cash transfer (or conditional cash transfer) to protect poor/vulnerable household from various types of shocks, including but not limited to the energy price increase.

\footnotetext{
${ }^{21}$ People/children with disabilities, WWII veterans and their spouses (and those similar in status), families of those who died in Chernobyl or during execution of service duties, families with at least four children under 18, people who worked on the labor front during WWII, and survivors of the Leningrad blockade.
} 
Appendix Table 1. Average Monthly Expenditures on Energy

(By expenditure quintile and location in lei)

Energy Product

\begin{tabular}{ccccc}
\hline Quintile & Central Gas & LPG & Electricity & Central Heat \\
& $(1)$ & $(2)$ & $(3)$ & $(4)$
\end{tabular}

(1)

(2)

(3)

A. All households ${ }^{1}$

$\begin{array}{lcccc}\text { Poorest } & 6.3 & 2.7 & 27.9 & 0.6 \\ \text { Second } & 12.1 & 3.2 & 33.0 & 3.1 \\ \text { Third } & 14.2 & 4.0 & 38.9 & 8.6 \\ \text { Fourth } & 21.7 & 5.0 & 44.8 & 16.1 \\ \text { Richest } & 30.1 & 6.2 & 57.3 & 26.4\end{array}$

B. Connected households with positive expenditures ${ }^{2}$

$\begin{array}{llllc}\text { Poorest } & 38.4 & 76.0 & 33.2 & \ldots \\ \text { Second } & 47.8 & 70.3 & 37.7 & 101.8 \\ \text { Third } & 55.3 & 66.5 & 43.6 & 138.2 \\ \text { Fourth } & 65.9 & 65.5 & 49.8 & 168.4 \\ \text { Richest } & 72.3 & 70.9 & 67.9 & 165.8\end{array}$

Of which:

B1. Large Cities

$\begin{array}{llllc}\text { Poorest } & 28.2 & \ldots & 48.7 & \ldots \\ \text { Second } & 24.3 & \ldots & 57.5 & 101.9 \\ \text { Third } & 23.3 & \ldots & 69.1 & 138.7 \\ \text { Fourth } & 27.0 & \ldots & 73.3 & 168.4 \\ \text { Richest } & 38.2 & \ldots & 92.8 & 165.4\end{array}$

B2. Small towns

$\begin{array}{lcccc}\text { Poorest } & 42.7 & 79.4 & 41.5 & \ldots \\ \text { Second } & 51.5 & 80.3 & 41.4 & \ldots \\ \text { Third } & 68.2 & 77.0 & 46.0 & \ldots \\ \text { Fourth } & 101.6 & 70.3 & 50.4 & \ldots \\ \text { Richest } & 131.6 & 76.5 & 65.0 & \ldots \\ \text { Rural areas } & & & & \\ \text { Poorest } & 34.7 & 73.7 & 30.6 & \ldots \\ \text { Second } & 62.5 & 65.2 & 34.3 & \ldots \\ \text { Third } & 84.2 & 64.4 & 38.0 & \ldots \\ \text { Fourth } & 124.8 & 64.4 & 40.9 & \ldots \\ \text { Richest } & 139.3 & 70.3 & 48.4 & \ldots \\ & & & & \end{array}$

Source: HBS and Bank staff calculations.

Note: "..." indicate insufficient observations.

${ }^{1}$ Unconnected households as well as households that are connected but have missing expenditure data are assumed to have zero expenditures on energy.

${ }^{2}$ Includes only households that are connected and are reporting expenditure information. Implicitly, the calculations include households that are connected but have missing expenditure data, and these households are assumed to have expenditure levels equal to average expenditures by quintile and location. 
Appendix Table 2. Impact of Gas Price Increase: Assuming Base Consumption Levels Are Unchanged (No Substitution) (By expenditure quintile and location in percent of total household consumption)

\begin{tabular}{|c|c|c|c|c|c|c|c|c|}
\hline \multirow[b]{2}{*}{$\begin{array}{l}\text { Magnitude of price increase/ } \\
\text { Quintile }\end{array}$} & \multicolumn{4}{|c|}{ Scenario 1: Impact by Energy Product } & \multicolumn{4}{|c|}{ Scenario 2: Impact by Energy Product } \\
\hline & $\begin{array}{c}\text { Central Gas } \\
37.5 \% \\
(1)\end{array}$ & $\begin{array}{c}\text { LPG } \\
37.5 \% \\
(2)\end{array}$ & $\begin{array}{c}\text { Electricity } \\
30 \% \\
(3)\end{array}$ & $\begin{array}{c}\text { Central Heat } \\
37.5 \% \\
(4)\end{array}$ & $\begin{array}{c}\text { Central Gas } \\
100.0 \% \\
\text { (5) }\end{array}$ & $\begin{array}{c}\text { LPG } \\
100.0 \% \\
(6)\end{array}$ & $\begin{array}{c}\text { Electricity } \\
80 \% \\
(7)\end{array}$ & $\begin{array}{c}\text { Central Heat } \\
100.0 \% \\
(8)\end{array}$ \\
\hline \multicolumn{9}{|l|}{ A. All households ${ }^{1}$} \\
\hline Poorest & 0.4 & 0.2 & 1.6 & 0.0 & 1.0 & 0.4 & 5.4 & 0.1 \\
\hline Second & 0.7 & 0.1 & 1.5 & 0.2 & 1.8 & 0.4 & 4.9 & 0.4 \\
\hline Third & 0.6 & 0.2 & 1.5 & 0.4 & 1.7 & 0.4 & 4.9 & 1.0 \\
\hline Fourth & 0.8 & 0.2 & 1.4 & 0.6 & 2.1 & 0.5 & 4.5 & 1.5 \\
\hline Richest & 0.7 & 0.1 & 1.1 & 0.7 & 1.9 & 0.4 & 3.6 & 1.8 \\
\hline \multicolumn{9}{|c|}{ B. Connected households with positive expenditures ${ }^{2}$} \\
\hline Poorest & 2.4 & 4.2 & 1.9 & $\ldots$ & 6.4 & 11.3 & 6.5 & $\ldots$ \\
\hline Second & 2.7 & 3.3 & 1.7 & 5.4 & 7.1 & 8.7 & 5.6 & 14.4 \\
\hline Third & 2.5 & 2.7 & 1.6 & 6.1 & 6.6 & 7.1 & 5.5 & 16.1 \\
\hline Fourth & 2.4 & 2.3 & 1.5 & 5.9 & 6.3 & 6.3 & 5.0 & 15.8 \\
\hline Richest & 1.7 & 1.7 & 1.3 & 4.1 & 4.6 & 4.4 & 4.3 & 11.0 \\
\hline \multicolumn{9}{|l|}{ Of which: } \\
\hline \multicolumn{9}{|l|}{ B1. Large Cities } \\
\hline Poorest & 2.1 & $\ldots$ & 2.3 & $\ldots$ & 5.5 & $\ldots$ & 7.8 & $\ldots$ \\
\hline Second & 1.3 & $\ldots$ & 2.4 & 5.4 & 3.6 & $\ldots$ & 8.0 & 14.3 \\
\hline Third & 1.2 & $\ldots$ & 2.4 & 6.1 & 3.2 & $\ldots$ & 7.9 & 16.1 \\
\hline Fourth & 1.0 & $\ldots$ & 2.1 & 5.9 & 2.6 & $\ldots$ & 6.9 & 15.8 \\
\hline Richest & 0.8 & $\ldots$ & 1.6 & 4.1 & 2.1 & $\ldots$ & 5.3 & 11.0 \\
\hline \multicolumn{9}{|l|}{ B2. Small towns } \\
\hline Poorest & 2.8 & 5.0 & 2.4 & $\ldots$ & 7.3 & 13.2 & 7.9 & $\ldots$ \\
\hline Second & 3.2 & 4.5 & 2.0 & $\ldots$ & 8.4 & 12.0 & 6.8 & $\ldots$ \\
\hline Third & 3.2 & 3.9 & 1.9 & $\ldots$ & 8.6 & 10.5 & 6.3 & $\ldots$ \\
\hline Fourth & 4.0 & 3.3 & 1.7 & $\ldots$ & 10.6 & 8.8 & 5.6 & $\ldots$ \\
\hline Richest & 3.9 & 2.4 & 1.4 & $\cdots$ & 10.4 & 6.3 & 4.8 & $\cdots$ \\
\hline \multicolumn{9}{|l|}{ B3. Rural areas } \\
\hline Poorest & 1.9 & 3.8 & 1.8 & $\ldots$ & 5.0 & 10.0 & 6.1 & $\ldots$ \\
\hline Second & 3.0 & 3.0 & 1.5 & $\ldots$ & 7.9 & 8.0 & 5.0 & $\ldots$ \\
\hline Third & 3.1 & 2.4 & 1.4 & $\ldots$ & 8.3 & 6.4 & 4.7 & $\ldots$ \\
\hline Fourth & 3.8 & 2.2 & 1.2 & $\ldots$ & 10.2 & 5.8 & 4.2 & $\ldots$ \\
\hline Richest & 2.8 & 1.6 & 1.0 & $\ldots$ & 7.6 & 4.2 & 3.3 & $\ldots$ \\
\hline
\end{tabular}

Source: HBS and Bank staff calculations.

Note: "..." indicate insufficient observations. Based on a arithmetic mean of the relative price change.

${ }^{1}$ Unconnected households as well as households that are connected but have missing expenditure data are assumed to have zero expenditures on energy.

${ }^{2}$ Includes only households that are connected and are reporting expenditure information. Implicitly, the calculations include households that are connected

but have missing expenditure data, and these households are assumed to have expenditure levels equal to average expenditures by quintile and location. 
Appendix Figure 1. The Prices of Natural Gas 2005

(Excluding taxes)

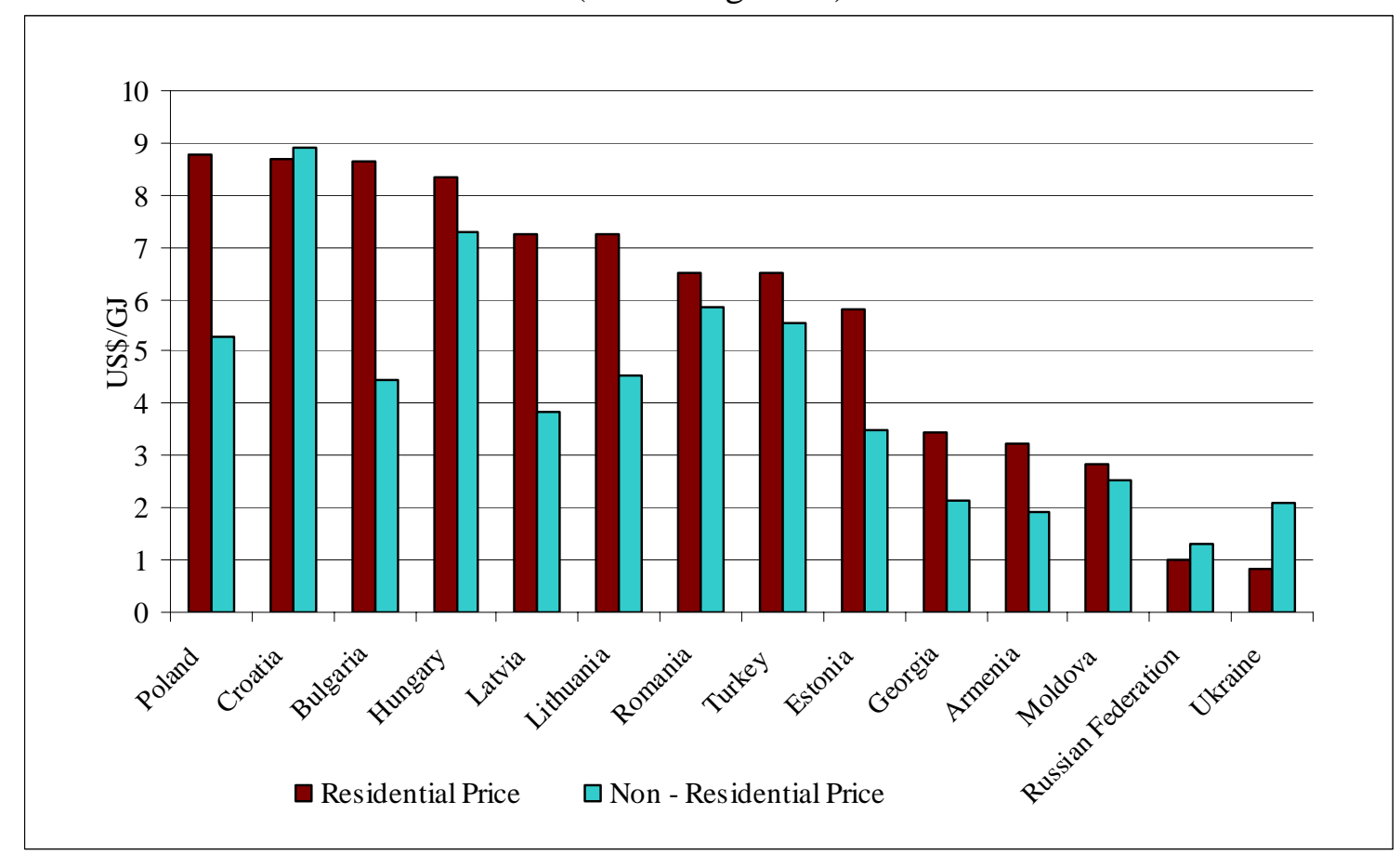

Appendix Figure 2. The Prices of Electricity 2005

(Excluding taxes)

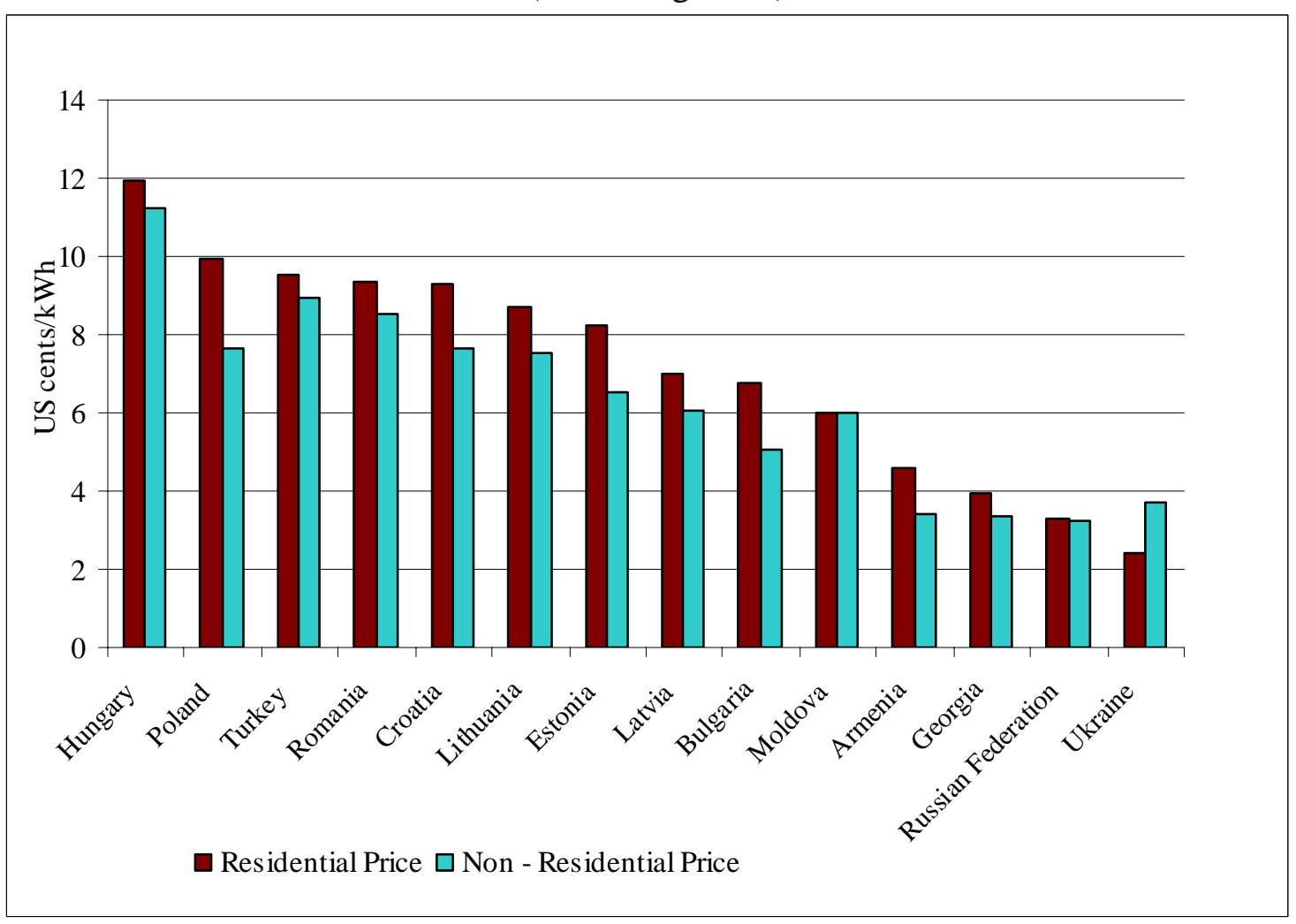




\section{TeChNical ApPEndix}

\section{Two Indexes of Price Change}

This technical appendix is based heavily on the discussion of indexes of price change in Pollak (1989), Gupta and others (2000), and U.S. Bureau of Labor Statistics $(1997)^{22}$. The paper uses two measures of the increases in the cost of living or the corresponding fall in real income: one based on an arithmetic index of relative price change, the other is based on a geometric index of price change. These are two widely used measures of relative price change and also underlie recent debates (such as on the U.S. CPI) on how best to account for substitution in measuring relative price change.

The arithmetic index, also known as the Laspeyres index, is a measure of relative price change $\mathbf{R}^{\mathbf{A}}$ from time $t$ to time $t+1$, based on a comparison of the sum of weighted prices in time $t+1$ with the sum of the weighted prices in time $t+1$, keeping the same exact items and the same exact quantities as in the base period in the consumption basket. It is calculated as follows:

$$
R^{A}=\frac{\sum P_{t+1, i} Q_{t, i}}{\sum P_{t, i} Q_{t, i}}
$$

where $P_{t+1, i}$ and $P_{t, i}$ are the prices of the $i$-th item in the comparison and base periods, respectively, and $Q_{t, i}$ is the quantity of the $i$-th item consumed in the base period.

The geometric index is a measure of relative price change $\mathbf{R}^{\mathbf{G}}$ from time $t$ to time $t+1$, using the share of consumption items in the household expenditure as weights:

$$
R^{G}=\prod\left(\frac{P_{t+1, i}}{P_{t, i}}\right)^{w_{t, i}}
$$

where $P_{t+1, i}$ and $P_{t, i}$ are the prices of the $i$-th item in the comparison and base periods, respectively, and $w_{t, i}$ is the share of the $i$-th item in total household expenditure. The relationship of equation (1) to equation (2) can be seen by rewriting the arithmetic or Laspeyres formula as an arithmetic mean of price relatives, weighted by expenditure shares from the base period:

$$
R^{A}=\sum w_{t, i}\left(\frac{P_{t+1, i}}{P_{t, i}}\right)
$$

\footnotetext{
${ }^{22}$ See also Dalton and others (1998) and Shapiro and Wilcox (1998).
} 
Equivalently, one could think of $\mathbf{R}^{\mathbf{A}}$ and $\mathbf{R}^{\mathbf{G}}$ as measures of compensations needed to make the household as well off as they were prior to the price change; in other words, household utility or well-being is kept constant or at base period levels. In the case of the arithmetic or Laspeyres index, this is consistent with the items and quantities of consumption being kept constant, with underlying preferences that can be described by a Leontief utility function (i.e., no substitution). In the case of the geometric index of relative price change, the estimate reflects Cobb-Douglas preferences, with expenditure shares constant across time and allowing for substitution away from relatively more expensive goods while keeping household utility constant. ${ }^{23}$

\section{Appendix Table 3. Two-Good Example}

\begin{tabular}{|c|c|c|c|c|c|}
\hline Goods & $Q^{t}$ & $\mathrm{P}^{\mathrm{t}}$ & $\begin{array}{c}\text { Base Period } \\
\text { Expenditure } \\
\mathrm{P}^{\mathrm{t}} \mathrm{Q}^{\mathrm{t}}\end{array}$ & $\begin{array}{l}\text { Base Period } \\
\text { Expenditure } \\
\text { Shares } \\
\text { (a), (1-a) }\end{array}$ & $\mathrm{P}^{\mathrm{t}+1}$ \\
\hline Good X & 1.00 & 1.00 & 1.00 & 0.50 & 1.50 \\
\hline Good Y & 1.00 & 1.00 & 1.00 & 0.50 & 1.00 \\
\hline
\end{tabular}

For example, suppose a household consumes only two goods (X and $\mathrm{Y}$ ). Appendix Table 3 reports the base period prices and consumption as well as the expenditure. ${ }^{24}$ Assume that the base period prices are both 1.00 and total expenditure is 2.00. Suppose the price of good $\mathrm{X}$ rises in the next period to 1.50 .

Using the arithmetic index (equation 3), the relative price change is equal to 1.25 $=[(0.5 * 1.5)+(0.5 * 1.00)]$ representing a 25 percent increase in prices or a 25 percent fall in real household income. Using the geometric index, the price change would only be 22.5 percent, or $22.5=\left[(1.5)^{0.5 *}(1.0)^{0.5}\right]$, as it allows changes in spending patterns in response to changes in relative prices. To compensate for the fall in real income, the arithmetic index implies a compensation of $0.50=0.25 *(2.00)$. The household can then spend 2.50 on the base period quantities and keep Leontief utility constant, $\mathrm{U}=$ $\min \{X, Y\}$.

The geometric index, however, implies only a compensation of $0.45=$ $0.225 *(2.00)$. In this second case, the household can spend 2.45 on goods $\mathrm{X}$ and $\mathrm{Y}$ while keeping expenditure shares constant. In particular, the household can buy 0.82 unit of

\footnotetext{
${ }^{23}$ The expression for $\mathrm{R}^{\mathrm{G}}$ is equal to the ratio of the Cobb-Douglas expenditure function for the reference period to the expenditure function of the base period (see also Pollak 1989)

${ }^{24}$ The example is drawn from BLS (1997).
} 
good $\mathrm{X}$ and 1.22 units of good $\mathrm{Y}$; at the new price levels, expenditure shares remain constant $(0.50$ each or $1.22=0.82 * 1.50=1.22 * 1.00)$. Given Cobb-Douglas preferences $\left(\mathrm{U}=\left[(\mathrm{X})^{\mathrm{w} *}(\mathrm{Y})^{1-\mathrm{w}}\right]=\left[(\mathrm{X})^{0.5 *}(\mathrm{Y})^{0.5}\right]\right.$, the level of utility is unchanged. In this case $\mathrm{U}=1=$

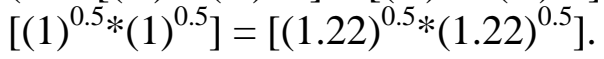

Which measure of price change or fall in real income is more appropriate? It depends on whether possibilities for substitution exist but the two approaches should provide a reasonable range of estimates. 


\section{REFERENCES}

Dalton, Kenneth V., John S. Greenlees and Kenneth J. Stewart. 1998. “Incorporating a geometric mean formula into the CPI,” Monthly Labor Review, October: 3-7.

Freund, Caroline L. and Christine Wallich. 1997. "Public Sector Price Reforms in Transition Economies Who Gains? Who Loses? The Case of Household Energy Prices in Poland,” Economic Development and Cultural Change Vol. 46, No. 1 (October 1997): 35-59.

Gupta, Sanjeev, Marijn Verhoeven, Robert Gillingham and others. 2000. Equity and Efficiency in the Reform of Price Subsidies: A Guide for Policymakers (Washington: International Monetary Fund).

Junge, Nils, Taras Pushak, Julian Lampietti, Nora Dudwick and Katelijn Van den Berg. 2004. Sharing Power: Lessons Learned from the Reform and Privatization of Moldova's Electricity Sector (Washington: The World Bank).

Lampietti, Julian, ed. 2004. Power's Promise: Electricity Reforms In Eastern Europe And Central Asia (Washington: The World Bank).

Pollak, Robert A. 1989. The Theory of the Cost-of-Living Index, Oxford University Press.

Shapiro, Matthew D. and David Wilcox. 1997 “Alternative Strategies for Aggregating Prices in the CPI,” Federal Reserve Bank of St. Louis Review Vol. 79, No. 3 (May-June 1997): 113-25

U.S. Bureau of Labor Statistics. 1997. "The Experimental CPI using Geometric Means (CPI-U-XG),” (Washington: U.S. Bureau of Labor Statistics).

World Bank. 2004. Recession, Recovery and Poverty in Moldova, Vol. II: Technical Background Papers. Report No. 28024-MD. (Washington: The World Bank). 